\title{
Examining the Effects of Geography Lessons Taught with Place Based Teaching to Science Process Skills for Classroom Teacher Candidates ${ }^{*}$
}

\author{
Nihal Yıldiz Y1lmaz \\ Correspondence: Nihal Yıldız Yılmaz Karamanoglu Mehmetbey University, Faculty of Education, Department of \\ Primary Education, Classroom Teaching, Karaman, Turkey.
}

Received: October 17, 2018

Accepted: December 19, 2018

Online Published: December 21, 2018

doi:10.11114/jets.v7i2.3693

URL: https://doi.org/10.11114/jets.v7i2.3693

\begin{abstract}
The aim of this research is to examine the effects of the General Geography lessons, which are taught by using place, based teaching activities, on the science process skills for classroom teacher candidates. A nested pattern, which is one of the mix method research patterns, is used for this research. The quasi-experimental design with pre-test and post-test control group is used in the quantitative part, which is in accordance with the mixed method research; whereas in qualitative part, case study is used. The study group of the research consists of first year teacher candidates who study at Karamanoglu Mehmetbey University, Department of Classroom Teaching. In the experimental group of the study, in accordance with the place based teaching activities, the General Geography lesson was taught outside the classroom for 4 weeks, and in the control group, the course was taught in the classroom in accordance with the program. As a result of the research, between the experimental group and control group students, no significant difference is found in pre-test, while a significant difference is found in post-test. A significant difference is found between the pre test-post test average points, in favor of post-test, regarding science process skills of the students in the experimental group.
\end{abstract}

Keywords: place based teaching, general geography, science process skills

\section{Introduction}

A region where people are present and which occupies a certain area is called a place, and places and people are in constant interaction. There are three types of interaction between people and their environment:

1) People's adaptation to their environment,

2) People changing their environment,

3) People depending on their environment (Efe, 2002).

Education ensures to establish a positive interaction between people and their environment. As a matter of fact, when educational programs around the world are examined, it is seen that the programs are not created independently of places. The place based teaching approach has emerged as an environment based teaching approach based on place. Place based teaching is the process of using the local community and environment as a starting point to teach the general curriculum in arts, mathematics, social studies, science and other subjects (Sobel, 2004). The approach for enabling students to think in complex thoughts about their families, their cities and their surroundings is the place based teaching approach (Altman, Stires \& Weseen, 2015). Regarding learning, place based learning is an educational approach that is used as an integrated context to learn all aspects of the local environment, including cultural, historical and sociopolitical situations and the natural and artificial environment (Chin, 2001).

The purpose of the place based teaching approach is to provide students with a sense of belonging by helping them understand the physical and humane qualities of the place they live in, and providing them with the necessary knowledge and skills so that they are able to offer solutions to local problems (Köşker \&Karabağ, 2012). Place based education aims to promote sustainable lifestyles and economies that are ecologically and culturally appropriate for places and regions (Semken, 2005). The general benefits of place based education are as follows:

Increases academic achievements.

\footnotetext{
${ }^{*}$ This study was produced by the report presented at the 1st International Basic Education Congress.
} 
1) Increases graduation rate.

2) Creates better harmony between teachers and students.

3) Students are more motivated and prepared to enter the STEM fields.

4) Decreases the absence of students.

5) Increases learning time, reduces problem behaviors.

6) Allows students to spend more time outdoors and in the community, thus increases physical activity.

7) Increases social capital (Fly, 2010).

This education method, emphasizing the real life experiences, improves academic achievement, helps students to build stronger connections with the society, increases students' contribution to the natural world, and allows students to provide services to the society as active, contributing citizens (Sobel, 2004). With the place based teaching approach, problems related to the lack of connection between students and local authorities or communities can be solved (Bartholomaeus, 2006). In the process of solving the problems, students are expected to use certain skills. The science process skill are one of them. As a matter of fact, one of the purposes in the Science Curriculum program, prepared by the Ministry of National Education (MEB, 2013), is defined as "the adoption of the approach of using science process skills for understanding environment and human relations in the discovery of nature".

The science process skills that enable students to gain an understanding of information. These skills allow students to create questions, and systematically and scienceally reveal answers (Hadi, 2016). Science process skills are the skills to better understand the subject, to think, to ask questions, to search for answers, to think about and solve problems, they consist of a lot of skills, such as observing, classifying, estimating, concluding, experimenting, interpreting data while structuring and organizing information (Aslan, Ertaş Kılıç \& Kılıç, 2016). The science process skills are divided into 14 science process skills in 3 sub-dimensions as seen in Table 1.

Table 1. Science Process Skills Sub-Dimensions

\begin{tabular}{lll}
\hline & Science Process Skills & \\
\hline Basic Processes & Experimental Processes & Causative Processes \\
\hline 1. Observation & 1. Estimation & 1. Creating a hypothesis \\
2. Quantification & 2. Defining variables & 2. Using data and creating value \\
3. Classification & 3. Interpreting data & 3. Experimenting \\
4. Saving Data & 4. Reaching a conclusion & 4. Changing and controlling the variables \\
5. Establishing a connection between number and space & & 5. Reaching a decision \\
\hline
\end{tabular}

(Çepni, Ayas, Johnson \& Turgut, 1996).

Although science seems to be progressing spontaneously through processes such as curiosity, asking questions, and exploring, there is a need for support to improve science process skills (Jirout \& Zimmerman, 2015). While basic skills may be learned starting from pre-school period, more complex skills (experimental and causative skills) may be learned starting from secondary school. What is expected of every individual who has passed these periods is to learn this skill to a certain degree (Ergin, Şahin Pekmez \& Öngel Erdal, 2012). Science process skills are among the skills expected to be more complex and increase from preschool period.

When the science process skills are examined in the literature, they are mostly studied together with the field of Science (Tan \& Temiz, 2003; Bozdoğan, Taşdemir \&Demirbaş, 2006; Yamak, Bulut \& Dündar, 2014; Şahin, Aydın \& Yurdakul, 2016; Bahtiyar \& Can, 2017; Prajoko, Amin, Rohman, \& Gipayana, 2017). Science process skills can be applied in all lessons, however with education, they should also become an indispensable part of daily life. The importance of science process skills is emphasized with regards to enabling students to recognize their physical environment (Çepni, Ayas, Johnson \& Turgut, 1996).

The purpose of the place based teaching approach is to search for solutions to environmental problems. Science thinking skills are being utilized in the process of introducing and implementing solutions to problems. For this reason, the study aims to determine the relationship between the place based teaching approach and science thinking skills. This study will contribute to the literature because there are very few studies on place based teaching and place based teaching is not related to science process skills. The aim of this research is to examine the effects of the General Geography course, which is taught by place based teaching activities, on the science process skills for first grade prospective teachers in the classroom teacher program. In line with this main objective, following questions tried to be answered:

1. Is there a meaningful difference between the pre-test and post-test scores in terms of the science process skills of the students, who are thought with place based activities?

2. Is there a meaningful difference between pre-test and post-test scores for the science process skills of students who are taught with the current curriculum? 
3. Is there a meaningful difference between the post-test scores of the students who are taught with place based teaching activities and those who are taught with current teaching program?

4. What are the opinions of the students in the experimental group on the General Geography course, which is taught by place based teaching?

5. What are the suggestions for the contribution and development of place based teaching of students taught with place based teaching activities?

\section{Method}

In the study, one of the mixed study patterns, intertwined patterns are used. The mixed method consists of activities involving several stages (Creswell, 2014). This research method is defined as a research in which the researcher collects and analyzes the data and reaches conclusions using qualitative and quantitative approaches and methods in a single study. In the case of intertwined patterns, the researcher may add a qualitative phase to a quantitative phase such as experimental study, or add a quantitative phase to a qualitative case study. In this pattern, supportive phase is added with the aim of improving the overall pattern (Creswell \& Plano Clark, 2011). In line with the research problem, a qualitative phase was added to this experimental study, aimed at determining the effects of the nature education program applied to primary school students at different socioeconomic levels, on environmental awareness levels, and the general pattern of the study is supported. The quasi-experimental design with pre-test and post-test control group is used in the quantitative part, which is in accordance with the mixed method research; whereas in qualitative part, case study is used.

\subsection{Study Group}

The study group of the research consists of first year teacher candidates who study at Karamanoglu Mehmetbey University, Department of Classroom Teaching. According to the success of the students in the university entrance exams, students with single student numbers are placed in one class and the students with double student numbers are placed in another class, thus two equal classes are created. A class is randomly selected as the control group, and the other becomes the experimental group. Seven students who did not participate actively in pre-test and post-test and experimental study were excluded from the study. Both control and experimental group consist 29 students.

\subsection{Data Collection Methods}

A 36-item, multiple-choice Science Process Skills Test, developed by Burns, Okey and Wise (1985) and adapted to Turkish by Geban, Aşkar and Özkan is used as a data collection tool in the study. In the original scale, the reliability coefficient was 0.86 (Burns, Okey \& Wise, 1985). In the study conducted with the scale adapted to Turkish, the reliability coefficient was found to be 0.81 (Özkan, Aşkar \& Geban, 1992). In the study carried out by Kanlı and Temiz (2006), with teacher candidates, the reliability coefficient of the test was determined as 0.79 . Therefore, the Science Process Skills Test is considered as a reliable scale.

\subsection{Data Collection}

For the experimental group of the study, in accordance with the place based educational activities, the General Geography course was taught out of class for 4 weeks, and in the control group, lessons were taught in the classroom in accordance with the current curriculum. At the same time, extracurricular activities (sightseeing, observation, group work) were carried out for 4 weeks, to support place based teaching activities.

\subsection{Experimental Activities}

The following are performed during experimental activities:

$\checkmark$ A trip was organized to a public picnic area and students were asked to note the positive and negative aspects of the environment.

$\checkmark$ Other people who came to the picnic area were also asked about their opinions on the conditions and their answers were noted down.

$\checkmark$ Students created solution proposals in groups, according to these notes.

$\checkmark$ Negotiations were held with the people responsible for the picnic area and negative aspects are discussed.

$\checkmark$ Later, feedback was received from the officials regarding proposed solutions.

$\checkmark$ A solution proposal was developed in line with the feedback and was discussed with authorized people.

$\checkmark$ Oral and written reports were presented.

$\checkmark$ Activities were carried out to raise public awareness (brochure, poster).

$\checkmark$ Clean-up activities were conducted to raise awareness of university staff and students. 
$\checkmark$ The trees in campus were put under protection.

\subsection{Analysis of Data}

Analyzes are made to see if the data showed a normal distribution. According to the results of the Kolmogorov-Smirnov test on the distribution of pre-test and post-test data of students who participated in the study, it is determined that pre-test and post-test data are not normally distributed ( $p>.05)$. In the scope of the study, nonparametric tests are performed because the data is not distributed normally.

Analysis of the data of semi-structured interview form obtained from the research is done by content analysis. Content analysis is a systematic and reproducible technique in which the desired messages are identified and conclusions are reached using coding done according to certain rules (Büyüköztürk, Çakmak, Akgün, Karadeniz \& Demirel, 2009). In content analysis approach, categories are determined qualitatively for texts, and quantitatively the frequency of categories is determined (Mayring, 2014). Content analysis provides new ideas and makes it easier for the researcher to understand certain events (Krippendorff, 2004). Content analysis is used for discovering concepts and relationships that can explain the collected data, and analysis is done in 4 steps:

1) Coding the data

2) Finding themes

3) Organizing codes and themes

4) Defining and interpreting the findings (Yıldırım \& Şimşek, 2006).

Accordingly, the data from the study is coded as K. Themes are created by analyzing the content of each question and quantitative data is given under each theme. In order to ensure the reliability of the qualitative data in the study, two procedures are performed. First, the data that can be represented in each category are directly quoted without comment. Secondly, expert opinion is sought in order to determine whether the statements under 37 conceptual categories of the experimental group in the research represent the category in question. For this purpose, two forms have been given to an expert. The first form contains 37 conceptual categories belonging to the experimental group and the second one contains the list of 167 responses given by the students. The expert is asked to match 37 conceptual categories with 167 answers, using the two lists. Matches made by the expert and the researcher are compared. The number of "agreements" and "disagreements" are stated after comparison. The reliability of the study is calculated using the formula of Miles and Huberman (1994) (Reliability = agreements / agreements + disagreements X 100). In the matches made by the expert and the researcher, for the "Making interpretations" category, 1 response is found in different categories. Therefore, the Reliability is calculated as: Reliability $=167 / 167+1 \mathrm{X} 100=99.4 \%$ In qualitative research, when the agreement experts and researchers is $90 \%$ and above, the research is considered reliable (Miles \& Huberman, 1994). The identification and interpretation of findings are carried out together with quantitative analysis results.

\section{Findings}

The normality test was performed to determine the distribution of the data. According to the results of the Kolmogorov-Smirnov Test used for groups with an observation number of 50 and above (Alpar, 2014), the significance value for the pre-test is 008 , and for the post test007, thus it is determined that the data is not normally distributed and non-parametric analyzes are carried out.

Mann Whitney U Test is performed to determine whether there is a difference in the pre-tests between two groups and the results are presented in Table 2.

Table 2. For the students in the Experimental-Control Group, the Science Process Skills Test Scale, the Mann Whitney $\mathrm{U}$ Test for Pre-test Score Averages

\begin{tabular}{cccccc}
\hline Pre-test & n & Average Score & Total Score & U & P \\
\hline Control & 29 & 30.74 & 891.50 & 384.500 & .573 \\
Experiment & 29 & 28.26 & 819.50 & & \\
\hline
\end{tabular}

The results of the Mann Whitney U Test in Table 2, conducted to determine whether there is a significant difference between the experimental and control group students' pre-tests of science process skills, are examined and is determined that $\mathrm{p}=.573$, and since $\mathrm{p}>0.05$, there is no significant difference between the pre-test averages.

Mann Whitney U Test test is conducted to determine whether there is a significant difference in the post-test results among the groups and the results are presented in Table 3:

In Table 3, according to the results of the Mann Whitney U Test conducted to determine whether the science process skills post-tests of experimental and control group students exhibit meaningful difference, a meaningful difference is found $(\mathrm{U}=266.000, \mathrm{p}<.05)$ and when the average scores are examined, it is determined that the experimental group had 
a higher score regarding science process ability than the control group.

Table 3. For the students in the Experimental-Control Groups, the Science Process Skills Test Scale, the Mann Whitney U Test for Post-test Score Averages

\begin{tabular}{cccccc}
\hline Pre-test & n & Average Score & Total Score & U & P \\
\hline Control & 29 & 24.17 & 701.00 & 266.000 & $.015^{*}$ \\
Experiment & 29 & 34.83 & 1010.00 & & \\
\hline
\end{tabular}

The results of the Wilcoxon Signed Ranks Test conducted to determine whether the pre and post-test results of the students in the control group show differences, are presented in Table 4.

Table 4. For students in the control group, the results of the Wilcoxon Signed Ranks Test for average scores of pretest-posttest in Science Process Skills Test Scale

\begin{tabular}{cccccc}
\hline Pretest-Posttest & n & Average Score & Total Score & z & P \\
\hline Negative Ranks & 15 & 13.27 & 199.00 & -.989 & .323 \\
Positive Ranks & 10 & 12.60 & 126.00 & & \\
Equal & 4 & & & & \\
\hline
\end{tabular}

a: based on negative ranks

In Table 4, according to the pre-test and post-test average scores of the students in the control group, when the Wilcoxon signed-rank test results is examined, it is seen that there is no significant difference between the pre-test and post-test average scores of the students in the control group regarding the science process skills $(\mathrm{z}=-.989, \mathrm{p}=.323)$.

For the students in the experimental group, the results of Wilcoxon Signed Ranks Test results, which aims to see if there is a difference between the science process skills in pre-test and post-test, are shown in Table 4.

Table 5. For students in the experimental group, Wilcoxon Marked Rank Test results for average scores of pretest-posttest Science Process Skill Test Scale scores

\begin{tabular}{cccccc}
\hline Pretest-Posttest & $\mathbf{n}$ & Average Score & Total Score & $\mathbf{z}$ & $\mathbf{P}$ \\
\hline Negative Ranks & 9 & 11.39 & 102.50 & -2.085 & $.037^{*}$ \\
Positive Ranks & 18 & 15.31 & 275.50 & & \\
Equal & 2 & & & & \\
\hline
\end{tabular}

a: based on negative ranks

In Table 5, according to the pre-test and post-test average scores of the students in the experimental group, when the Wilcoxon signed-rank test results is examined, it is seen that there is a significant difference between the pre-test and post-test average scores of the students in the experimental group regarding the science process skills $(\mathrm{z}=-2.085$, $\mathrm{p}=.037$ ). Taking into consideration the average rank and the totals of the scores, post-test results are found to be higher.

The opinions of students in the experimental group on the lessons with the place based approach are presented in Table 6.

Table 6. The opinions of students in the experimental group on the lessons with the place based approach

\begin{tabular}{llc}
\hline & \multicolumn{1}{c}{ Opinions } & f \\
\hline & Increases retention of information & 17 \\
Eositive & Enables the students to learn on the site & 15 \\
& Interesting & 8 \\
& Makes information meaningful & 7 \\
& Increases awareness and knowledge & 3 \\
& Helps students like the lessons & 3 \\
& Enables students gain knowledge in a short time & 1 \\
& Provides cultural richness & 1 \\
\hline Problem of Time & 11 \\
Problem of Cost & 9 \\
& None & 5 \\
& Loosing attention & 3 \\
& Unfavorable weather conditions & 3 \\
& Problem of security & 3 \\
& Problem of transport & 2 \\
& Problem of supervising students & 1 \\
& Problems when utilizing the environment & 1 \\
& Tiring & 1 \\
\hline
\end{tabular}

When Table 6 is examined, it is determined that the students in the experimental group expressed 55 positive and 40 negative opinions for the lessons with the place based teaching. When the positive opinions of the students are 
examined, it is seen that the most common response is "increases the retention of information" with 17,15 students explained "the benefits of on-site learning", 8 students said it "increases interest" towards the lesson or subject, and 7 students said it "gives information meaning". Apart from these, positive comments such as "raising awareness and knowledge" (3), "helping students like the lesson" (3), "enabling learning in a short time" (1) and "providing cultural richness" are expressed.

When the negative answers in Table 6 is examined, it is seen that "problem of time" is the most common with 11 answers since lessons take more time, 9 students said "problem of cost", 5 said "none" as the lessons have no negative aspects, 3 said "losing attention" since the learning environments is different, 3 said "unfavorable weather conditions", and 3 said "problem of security". In addition to these, "problem of transportation" (2 answers), "problem of supervising the students" (1 answer), "problems for utilizing the environment" (1 answer), "tiring" ( 1 answer) and "problem of taking notes" (1 answer) are expressed.

In accordance with the content analysis, some students' answers to the questions are presented directly in the following citation:

\section{$\checkmark$ Positive opinions}

"Increases the retention of information. Decreases the monotony of the lessons. Makes the lessons more fun. Attracts attention." (K17)

"Makes it easier to learn, enables getting information about a place more quickly, saves time." (K15)

\section{$\checkmark$ Negative opinions}

"Takes more time. It may be hard to supervise students and control the groups movements. It may be difficult to focus on the lesson." (K19)

"I don't think there was any negative aspects. On the contrary, it made us become aware of the city we are living in." K7.

"Takes to much time and it's costly." (K10)

The suggestions that the students in the experimental group made for contribution of the place based education and its development are presented in Table 7:

Table 7. The suggestions that the students in the experimental group made for contribution of the place based education and its development

\begin{tabular}{llc}
\hline & & Opinions \\
\hline & Increases retention & f \\
& Gaining new information & 13 \\
The contributions of place based & Making information meaningful & 6 \\
education & Increases awareness & 6 \\
& Attracts attention & 3 \\
& Makes lessons fun & 3 \\
& Enables active participation & 2 \\
& Enables implementation of knowledge & 1 \\
& Increases socializing & 1 \\
\hline & Enough & 9 \\
& More places may be visited & 7 \\
& May be implemented in other courses & 3 \\
& Different activities may be added & 2 \\
& Allocated time may be increased & 2 \\
& Students may be encouraged to be more active & 2 \\
& No idea & 2 \\
& Expert support may be increased in every area & 1 \\
& Games may be added & 1 \\
\hline
\end{tabular}

When Table 7 is examined, the suggestions made by the students in the experimental group for the improvement of place based education are gathered under the themes of "contributions of place based education" with 43 answers and "suggestions for improvement" with 29 answers. When contributions of place based education theme is examined, it is seen that the most common answer is "increases retention" with 13 answers, "gaining new information" has 8 answers, "makes information meaningful" has 6 answers, "increases awareness" has 6 answers, "attracts attention" has 3 answers, "makes lessons fun" has 3 answers, "actively participating in class" has 2 answers, "implementing the knowledge" has 1 answer and "increases socialization" has 1 answer.

When the suggestions for improvement of place based teaching is examined, it is seen that the most common answer is "sufficient" with 9, 7 students said "more places may be visited", 3 said "may be implemented in other courses", 2 said 
"more activities may be added", 2 said "allocated time may be increased", 2 said "students may be encouraged to be more active", 2 said "no suggestions", 1 said "expert opinion may be increased in every area" and 1 said "games may be added".

In accordance with the content analysis, some students' answers to the questions are presented directly in the following citation:

\section{$\checkmark \quad$ The contributions of place based education}

"It was productive in terms of retention of knowledge and attracting attention." (K13)

"Increased the retention of the knowledge I gained. Classroom teaching would decrease the retention of this subject. I visited new places and also learned new things." (K26)

\section{$\checkmark \quad$ The suggestions for improvement}

"It may be implemented in all courses. Especially in Visual Arts and Music lessons, place based teaching may be used." (K14)

"The allocated time may be increased and the lessons may become related with other courses." (K24)

"Experts may provide more complex information." (K2)

\section{Conclusion and Discussion}

In the study, the pre-test and post-test scores for the students of the experimental and control groups are analyzed using a statistical program and it is tried to determined whether the place based teaching approach developed science process skills, and some results are gained. The place based teaching approach has a common science basis with Geography because of the concept of place, and has a connection with science process skills in terms of developing science thinking. As a matter of fact, in their study, Evans and Kılınç (2013) emphasized both geographical and science aspects of the place based teaching approach.

To determine if there is a difference between the science process skills of the experimental and control groups, the preliminary tests are analyzed and it is determined that there is no significant difference. When the post-test scores of the experimental group and the control group are examined, a significant difference is found in favor of the experimental group. The fact that there is a difference between post-test average scores of the students in the control and experimental group shows that the place based education has a significant effect on the science process skills of students. There was no significant difference between the pre-test and post-test average scores of the students in the control group. the fact that there is no meaningful difference between the pre-test scores and the post-test scores of the control group indicates that the current teaching program is insufficient in improving the science process skills. A significant difference is found between the pre-test and post-test average scores for the science process skills of the students in the experimental group. It is determined that the post-test average scores are higher. In this respect, it was determined that the students in the experimental group increased their science process skills with the place based teaching approach during the course of 4 weeks. When all the results obtained are examined, it has been determined that the place based teaching approach has a positive effect on students' science process ability.

The relevant literature reveals that the studies conducted in the natural environment increase the science process skills of students, in parallel with this study. According to the approach of discovery of the natural environment by Oktavia, Rahmawati, Alimah, Utami (2017), it has been determined that the science process skills of the students are increased by the experimental study in which the adaptive guided inquiry based learning model is applied. In the STEM study conducted by Braithwaite (2017) in a kindergarten, students analyzed animals and their habitats according to the stages of science process skills and constructed habitats suitable for the animals. As a result of the research, it has been determined that students gain more knowledge with science process skills. In the study conducted by Özdemir and Dikici (2017) with secondary school students, the researchers reached a conclusion that if the students understanding of natural science was fully developed, a harmony between science process skills and science creativity would be established, that is, all three are related to each other.

In the study, the answers given by the students in the experimental group to the semi-structured interview form about the place based teaching approach are analyzed by content analysis, coded, the themes are determined, the data is arranged and some results are obtained.

The experimental group has positive opinions about the place based approach and some students have expressed both positive and negative opinions. One of the most popular positive opinions, which more than half of the students agree upon, is that the method enabled students to engage all 5 senses, thus increased the retention of information. Other positive opinions include that the method enables on site learning with actual experience, makes information meaningful, and makes lessons more interesting. In line with these opinions, the students have negative opinions on 
implementing this method in the future on the ground of it taking too much time and being costly. However, when all opinions are taken into consideration, the fact that the positive opinions are high indicates that the students approve the place based teaching approach.

The students in the experimental group expressed at least one contribution of the place based teaching. The students expressed that the most important contribution is the retention of knowledge as they would never forget what they have learned. They also expressed that the approach made abstract information more concrete. This can be seen as an indication that concrete learning is always more attractive despite what age the student is. The place based teaching approach can be described as one of the most appropriate approaches in which abstract knowledge can be made more concrete. On the other hand, on-site learning provided by the place based teaching approach increases the diversity of information and the new information is acquired automatically. In terms of improvements for place based teaching approach, the students mostly found the approach sufficient. Furthermore, students' desire to use the place based teaching approach in other courses and their desire to go to more places can be interpreted as the method increasing the interest of students.

In the study conducted with Geography teachers by Köşker and Karabağ (2012), it has been determined that Geography teachers use classroom activities more frequently and plan fewer activities outside the classroom. The fact that many of the activities are class-centered has resulted in the students failing to make long-lasting and meaningful learning. These results and the conclusion of the research overlap in that the place based teaching approach is effective in terms of significance and retention of knowledge. In studies conducted by Takano, Higgins, McLaughlin (2009) and Smith (2007), it has been determined that the courses with place based teacing provides positive contributions (eg academic achievement, connection to society) to the students.

In line with the results of the research, the following suggestions can be made for researchers and teachers:

- Researchers can explore the relationship between place based teaching approach and other skills.

- The topics of the geography course can be planned and conducted in accordance with the place based teaching approach as it develops science process skills.

- In the light of the results of the research, place based teaching activities can be applied to every level from pre-school to undergraduate level in terms of effective community building, improvement of academic achievement and improvement of science process skills.

- The place based teaching approach can be used effectively by teachers and academics because it is effective in improving the science process skills and is applicable in other courses.

\section{References}

Alpar, R. (2016). Practical statistics and validity-reliability with examples from sports, health and educational sciences. Ankara: Detay Yayincilik.

Altman, R., Stires, S., \& Weseen, S. (2015). Claiming the promise of place-based education. Occasional Paper Series 33. Bank Street College of Education. https://educate.bankstreet.edu/occasional-paper-series

Aslan, S., Ertaş, Kılıç,. H., \& Kılıç, D. (2016). Science process skills. Ankara: Pegem Akademi. https://doi.org/10.14527/9786053183747

Bahtiyar, A., \& Can, B. (2017). An examination of the science process skills of science teacher candidates and their attitudes towards science research. Dokuz Eylul University, Journal of Buca Faculty of Education, (42), 47-58. http://dergipark.gov.tr/download/article-file/432047

Bartholomaeus, P. (2006). Some rural examples of place-based education. International Education Journal, 7(4), 480-489. http://hdl.handle.net/2328/3109

Bozdoğan, A. E., Taşdemir, A., \& Demirbaş, M. (2006). The effect of cooperative learning in science teaching to improve students' science process skills. Inonu University, Journal of Faculty of Education, 7 (11), 23-36. https://pegem.net/dosyalar/dokuman/8288-20110628163741-bozdogan.pdf

Braithwaite, S. (2017). Using the science process skills to investigate animals and animal habitats. Hofstra University.

Burns, J. C., Okey, J. R., \& Wise, K. C. (1985). Development of an integrated process skill test: TIPS II. Journal of Research in Science Teaching, 22(2), 169-177. https://doi.org/10.1002/tea.3660220208

Büyüköztürk, S., Çakmak, E., Akgün, O., Karadeniz, S., \& Demirel, F. (2009). Science research methods. 4th Edition. Ankara: Pegem Akademi.

Çepni, S., Ayas, A., Johnson, D., \& Turgut, M. F. (1996). Physics education. National Education Development Project, 
Pre-Service Teacher Training, Essay Edition. http://hskizilcik.com/fizik/egitim/FizikOgretimi.pdf

Chin, J. (2001). All of a place: Connecting schools, youth and community. In San Francisco: Funders' Forum on Environment and Education. (Institute Report of the Bay Area School Reform Collaborative-Funders' Learning Project). http://mitep.mtu.edu/include/documents/All-of-a-Place.pdf

Creswell, J. W. (2014). Research design, qualitative, quantitative and mixed approaches. Tra. Ed. Selcuk Besir Demir, 2017. Ankara: Eğiten Kitap.

Creswell, J. W., \& Plano, Clark,. V. L. (2011). Design and implementation of mixed method investigations. Tra. Yüksel Dede, Selcuk Besir Demir, 2014. Ankara: Anı Yayıncılık.

Efe, R. (2002). Five basic concepts in geography and their teaching methods and techniques. Marmara Cografya Dergisi (Marmara Journal of Geography), 5, 27-42. http://hdl.handle.net/11424/2436

Ergin, O., Şahin-Pekmez, E., \& Öngel-Erdal, S. (2012). From theory to practice, teaching science with experiments. İzmir: Dinazor kitapevi.

Evans, R. T., \& Kılınç, E. (2013). University of Adiyaman, Journal of Institute of Social Sciences, 14, 263-280. http://dergipark.gov.tr/download/article-file/15112

Fly, J. M. (2010). A place-based model for K-12 education in Tennessee. http://web.utk.edu/ markfly/documents/Place-Based\%20K-12\%20Education\%20Proposal\%205_10_10

Geban, O., Aşkar, P., \& Özkan, I. (1992). Effects of computer similation and problem solving approaches on high school. Journal of Educational Research, . 86 (1), 5-10. https://doi.org/10.1080/00220671.1992.9941821

Hadi, A. M. A. (2016). Students' perceptions of science laboratory learning experience to acquire integrated science process skills among undergraduate students at UPSI. Doctoral dissertation, Faculty of Science and Mathematics, Universiti Pendidikan Sultan Idris. http://ir.upsi.edu.my/id/eprint/1776

Jirout, J., \& Zimmerman, C. (2015). Development of science process skills in the early childhood years. In Research in Early Childhood Science Education (pp. 143-165). Springer, Dordrecht. https://doi.org/10.1007/978-94-017-9505-0_7

Kanlı, U., \& Temiz, B. K., (2006). The sufficiency of the numerical questions in the oss examination in the year 2003 on the measurement of the students' science process skills, Education and Science. 31(140), 62-67. http://egitimvebilim.ted.org.tr/index.php/EB/article/view/5008/1107

Köşker, N., \& Karabağ, S. (2012). Coğrafya eğitiminde yer temelli öğretim yaklaşımına ilişkin öğretmen görüşleri (Teacher views on the place based teaching approach in geography education). Türkiye Sosyal Araştırmalar Dergisi, 16 (3), 123-137. http://dergipark.gov.tr/download/article-file/200466

Krippendorff, K. (2004). Content Analysis: An İntroduction to Its Methodology. London: Sage Publications.

Mayring, P. (2014). Qualitative Content Analysis. Theoretical Foundation, Basic Procedures and Software Solution. Austria. www.files.qualitative-content-analysis.aau.at/

MEB. (2013). Primary education institutions primary schools and secondary schools science education curriculum. Ankara: Talim Terbiye Kurulu Başkanlığı (Board of Education).

Miles, M. B., \& Huberman, A. M. (1994). Qualitative data analysis. Tra. Ed. Sadegül Akbaba and Ali Ersoy, 2016, Ankara: Pegem Akademi.

Oktavia, R., Rahmawati, N. F., Alimah, S., \& Utami, N. R. (2017). The Effect of inquiry-based learning model by jas approach on students' science process skills. Journal of Biology Education, 6(3), 309-316. https://doi.org/10.15294/jbe.v6i3.21086

Özdemir, G., \& Dikici, A. (2017). Relationships between science process skills and science creativity: Mediating role of nature of science knowledge. Journal of Education in Science, Environment and Health, 3(1), 52-68. https://jeseh.net/index.php/jeseh/article/view/32

Prajoko, S., Amin, M., Rohman, F., \& Gipayana, M. (2017). The Usage of recycle materials for science practicum: is there any effect on science process skills?. International Journal of Evaluation and Research in Education, 6(1), 1-8. https://doi.org/10.11591/ijere.v6i1.6340

Şahin, S., Aydın, S. O., \& Yurdakul, B. (2016). Assessment of science process skills activities of science and technology course curriculum, seventh grade, human and environmental unit. Necatibey Eğitim Fakültesi Elektronik Fen ve Matematik Eğitimi Dergisi, 10(1), 32-59. http://dergipark.gov.tr/download/article-file/224364 
Semken, S. (2005). Sense of place and place-based introductory geoscience teaching for American Indian and Alaska Native undergraduates. Journal of Geoscience Education, 53(2), 149-157. https://doi.org/10.5408/1089-9995-53.2.149

Smith, G. A. (2007). Place-based education: Breaking through the constraining regularities of public school. Environmental Education Research, 13(2), 189-207. https://doi.org/10.1080/13504620701285180

Sobel, D. (2004). Place-based education: Connecting classroom and community. Nature and Listening, 4, 1-7. http://www.kohalacenter.org/teachertraining/pdf/pbexcerpt.pdf

Takano, T., Higgins, P., \& McLaughlin, P. (2009). Connecting with place: Implications of integrating cultural values into the school curriculum in Alaska. Environmental Education Researc., ,.15, 343-370. https://doi.org/10.1080/13504620902863298

Tan, M., \& Temiz, B. K. (2003). place and importance of science process skills in science teaching. Pamukkale Üniversitesi Ë̆itim Fakültesi Dergisi, 13(13), 89-101. http://dergipark.gov.tr/download/article-file/114823

Yamak, H., Bulut, N., \& Dündar, S. (2014). The effect of FETEMM activities on the students' attitudes towards science and process skills. Gazi Üniversitesi Gazi Eğitim Fakültesi Dergisi, 34(2), 249-265. http://gefad.gazi.edu.tr/article/download/5000078351/5000072574

Yıldırım, A., \& Şimşek, H. (2006). Qualitative research methods in the social sciences. 6. Edition. Ankara: Seçkin Yayıncilık.

\section{Copyrights}

Copyright for this article is retained by the author(s), with first publication rights granted to the journal.

This is an open-access article distributed under the terms and conditions of the Creative Commons Attribution license which permits unrestricted use, distribution, and reproduction in any medium, provided the original work is properly cited. 